\title{
Development of a Complementary and Alternative Medicine (CAM) Pharmacy and Therapeutics (P\&T) Subcommittee and CAM Guide for Providers
}

\author{
JEFFREY D. DUNN, PharmD, MBA; H. ERIC CANNON, PharmD; \\ TAMARA LEWIS, MD, MPA, MPH; and LAURA SHANE-MCWHORTER, PharmD, BCPS, FASCP, CDE
}

\begin{abstract}
OBJECTIVE: The objective was 2-fold: (1) to evaluate the feasibility and value of developing a Pharmacy and Therapeutics (P\&T) subcommittee aimed at scientifically evaluating complementary and alternative medicine (CAM) products for an integrated managed care organization (IMCO) and (2) to assess provider acceptance and usefulness of a CAM guide.

METHODS: Three factors drove the decision to form a CAM P\&T subcommittee to evaluate current commonly used CAM products: (1) physicians, pharmacists, and dieticians expressed a desire for an easy-to-use, scientifically based mechanism for evaluating the ever-increasing number of CAM products; (2) Intermountain Health Care Health Plans (Health Plans), the insurance division of this IMCO, offers access to certain CAM products to its members at a discounted price in an effort to remain competitive with other IMCOs; and (3) this IMCO owns and operates more than a dozen community pharmacies that sell CAM products. Some IMCO clinicians believed an efficacy and safety review of the products offered through the organization was warranted. Subcommittee members included clinical pharmacists (IMCO and university), pharmacy directors, a community pharmacist, practicing physicians (from the drug P\&T committee), a medical director, dieticians and nutritionists, and a representative from the Health Plans' sales department. The primary outcome was the development of a CAM guide listing recommendations for use of CAM products. Outcome measures included survey results (survey sent with guide to physicians and pharmacists) regarding acceptance and usefulness of the guide.
\end{abstract}

RESULTS: The CAM P\&T subcommittee met monthly to evaluate current commonly used CAM products. A CAM guide was developed in paperback and electronic versions. The electronic version was downloadable to handheld devices. Thousands of CAM guides were disseminated to IMCO-employed physicians, network pharmacies, dieticians, and nutritionists affiliated with this managed care organization. A survey that accompanied distribution of the first CAM guide in 2003 showed that $89 \%$ of physicians and pharmacists felt that the guide would be somewhat or very helpful as a counseling aide; the remainder was unsure. A second CAM guide was disseminated one year later, in 2004. The accompanying survey showed that $78 \%$ of physicians and $97 \%$ of pharmacists felt that the guide would be somewhat or very helpful as a counseling aide; $7 \%$ of physicians and $3 \%$ of pharmacists felt the guide would be unhelpful.

CONCLUSION: A CAM guide developed through the work of a subcommittee of the P\&T committee of this IMCO appears to be widely accepted by pharmacists and physicians. A CAM guide should be easy to use and available online with the ability to download to a handheld device.

KEYWORDS: Complementary and alternative medicine (CAM), Herbals, Integrated managed care organization (IMCO)

J Manag Care Pharm. 2005;11(3):252-58
I $\mathrm{n}$ the current health care environment, the main challenge for managed care organizations (MCOs) is to provide highquality medical and pharmaceutical care at an affordable cost. Maintaining affordable costs invokes many issues, one of which is to remain competitive with other MCOs by maintaining or increasing member enrollment and patient satisfaction.

Intermountain Health Care (IHC) is an integrated managed care organization (IMCO) in the state of Utah, which includes 21 hospitals, 25 health centers (outpatient clinics), InstaCare urgent care centers, and other facilities. In addition, it employs more than 450 physicians, owns and operates more than a dozen community pharmacies and a home health care service, and operates IHC Health Plans (Health Plans), a state-licensed insurer that covers approximately 475,000 lives in various health maintenance organization and preferred provider organization products. As one of many eff o rts to provide services valuable to members, Health Plans has offered sale of complementary and alternative medicine (CAM) products via its Web site. In addition, the IMCO-owned community pharmacies offer many CAM products for sale. As with prescription medications, an MCO has the responsibility to ensure the efficacy and safety of other products it endorses or allows to be used through its system.

Angell and Kassirer state, "There cannot be two kinds of medicine-conventional and alternative. There is only medicine that has been adequately tested and medicine that has not, medicine that works and medicine that may or may not work. Once a treatment has been tested rigorously, it no longer matters whether it was considered alternative at the outset. If it is found to be reasonably safe and effective, it will be accepted.

Authors

JEFFREY D. DUNN, Pha rmD, MBA, is clinical pharmacy coordinator and H. ERIC CANNON, PharmD, is director of pharmacy services, Intermountain Health Care Health Plans, Salt Lake City, Utah; TAMARA LEWIS, MD, MPA, $\mathrm{MPH}$, is medical director, Community Health and Prevention, Intermountain Health Care, Salt Lake City, Utah; LAURA SHANE-MCWHORTER, PharmD, BCPS, FASCP, CDE, is an associate professor, University of Utah College of Phamacy, Salt Lake City.

AUTHOR CORRESPONDENCE: Jeffrey D. Dunn, PharmD, MBA, Clinical Pharmacy Coordinator, Intermountain Health Care Health Plans, 4646 West Lake Park Blvd., Suite N3, Salt Lake City, UT 84120. Tel: (801) 442-7984;

Fax: (801) 442-3006; E-mail: jeffrey.dunn@ihc.com.

Copyright $\odot$ 2005, Academy of Managed Care Pharmacy. All rights reserved. 
But assertions, speculation, and testimonials do not substitute for evidence. Alternative treatments should be subjected to scientific testing no less rigorous than that required for conventional treatments." The work of MCOs in evaluating CAM products was made more difficult by the Dietary Supplement Health and Education Act of 1994, which eliminated the requirement that the U.S. Food and Drug Administration (FDA) review CAM products for efficacy, safety, and manufacturing standards if there is no claim to diagnose, treat, cure, or prevent disease. ${ }^{2}$

The first comprehensive and reliable data on the use of CAM in the United States were released in May 2004 by the National Center for Complementary and Alternative Medicine and the National Center for Health Statistics (NCHS, part of the Centers for Disease Control and Prevention). The data were derived from the 2002 edition of the NCHS's National Health Interview Survey, in which 31,044 noninstitutionalized American adults aged 18 years or older answered questions about their health- and illness-related experiences. The 2002 survey showed that $36 \%$ of adults are using some form of CAM. When megavitamin therapy and prayer specifically for health reasons are included in the definition of CAM, the proportion of American adults using CAM rises to $62 \%{ }^{3}$ The National Center for Complementary and Alternative Medicine (NCCAM) of the National Institutes of Health maintains a Web site with a wealth of information on CAM. ${ }^{4}$

The Slone Survey in 2001 found that 14\% of the population took herbals/supplements. Among prescription drug users, $16 \%$ also took an herbal/supplement. The authors concluded that the substantial overlap between use of herbals/supplements and prescription medications raises concerns about unintended interactions. ${ }^{5}$ However, many other sources estimate the use of CAM to be much higher. According to NCCAM, more than $42 \%$ of the American public used CAM in 1997, at a cost of $\$ 27$ billion per year, which exceeded out-of-pocket spending for all U.S. hospitalizations. ${ }^{6}$ David M. Eisenberg and colleagues estimated that, in 1990, the number of visits to providers of unconventional therapy in the United States exceeded the number of visits to all U.S. primary care physicians. ${ }^{7}$ Eisenberg reported that 4 out of 10 Americans used CAM therapies in 1997. His study also reported that the total number of visits to alternative medicine practitioners increased 50\% from 1990 to 1997, to 629 million visits per year. ${ }^{8}$ However, only $53 \%$ of CAM users report such use to their primary physicians. ${ }^{9}$

Responsible clinicians must be able to help their patients make informed decisions regarding therapeutic options, including those they may find unconventional. Patients increasingly want informed and shared decision making about their health. CAM use is an important component of modern health care. For this reason, IMCO clinicians expressed a desire for an easy-to-use, scientifically based mechanism for evaluating the ever-increasing number of CAM products.

\section{TABLE 1$)$ Evaluation Criteria for Products}

\begin{tabular}{l|l}
\hline Criteria & Definition \\
\hline Product & Alphabetized listing of herbal or natural entities \\
\hline Indication & Listing of proposed uses or common uses \\
\hline Efficacy & $\begin{array}{l}\text { Listing of those indications that are supported by } \\
\text { scientific evidence }\end{array}$ \\
\hline Adverse events & $\begin{array}{l}\text { Listing of common potentially harmful effects associated } \\
\text { with each entity }\end{array}$ \\
\hline Cautions & $\begin{array}{l}\text { Listing of drugs that may affect or be affected by each } \\
\text { entity }\end{array}$ \\
\hline Dosing & $\begin{array}{l}\text { Listing of contraindications and warnings that need to } \\
\text { be monitored }\end{array}$ \\
\hline Source & Clinically supported regimens for administration \\
\hline Recommendations & $\begin{array}{l}\text { Finding of origin and formulations } \\
\text { safe utilization }\end{array}$ \\
\hline
\end{tabular}

\section{TABLE 2 Information Sources}

\begin{tabular}{l|l}
\hline Information Source & Web Site, Reference, or Examples \\
\hline MICROMEDEX & www.micromedex.com \\
\hline $\begin{array}{l}\text { Review of Natural Products by } \\
\text { Facts and Comparisons }\end{array}$ & $\begin{array}{c}\text { Review of Natural Products by } \\
\text { Facts and Comparisons. St. Louis, MO. }\end{array}$ \\
\hline $\begin{array}{l}\text { Natural Medicines Comprehensive } \\
\text { Database }\end{array}$ & www.naturaldatabase.com \\
\hline $\begin{array}{l}\text { Journals cited through MEDLINE } \\
\text { searches }\end{array}$ & N Engl J Med, JAMA, UPhA Drug Info Line \\
\hline $\begin{array}{l}\text { Web sites } \\
\text { The German Commission E* }\end{array}$ & www.fda.gov; www.nih.gov \\
& www.herbalgram.org. The Complete \\
& $\begin{array}{l}\text { German Commission E Monographs. } \\
\text { Blumenthal M, Busse WR, Goldberg A, } \\
\text { et al., eds. }\end{array}$ \\
\hline Other & $\begin{array}{c}\text { Tyler's Herbs of Choice: The Therapeutic } \\
\text { Use of Phytomedicinals. Robbers JE, }\end{array}$ \\
& Tyler VE. \\
PDR for Herbal Medicines. Gruenwald \\
J, Brendler T, Jaenicke C, eds.
\end{tabular}

* The German Commission $\mathrm{E}$ is a German governmental regulatory agency that was established in 1978. It has evaluated the usefulness of more than 300 herbal products (through published monographs), utilizing literature, clinical studies, case studies, and field studies. The commission is composed of physicians, pharmacists, scientists, and toxicologists.

Given the desire to be responsive to its customersmembers and providers-Health Plans formed a group comprising an IMCO physician, a clinical pharmacist, and marketing and operations personnel to evaluate its contracted CAM vendor and its products. Health Plans Pharmacy Services began an evaluation of what was being offered and saw a significant opportunity for an intervention. One of its first 


\section{TABLE 3 Products Included in the CAM Guide*}

\begin{tabular}{|c|c|c|}
\hline Acceptable/Neutral Product & $\begin{array}{c}\text { Use With } \\
\text { Extreme Caution }\end{array}$ & $\begin{array}{c}\text { Not } \\
\text { Recommended }\end{array}$ \\
\hline 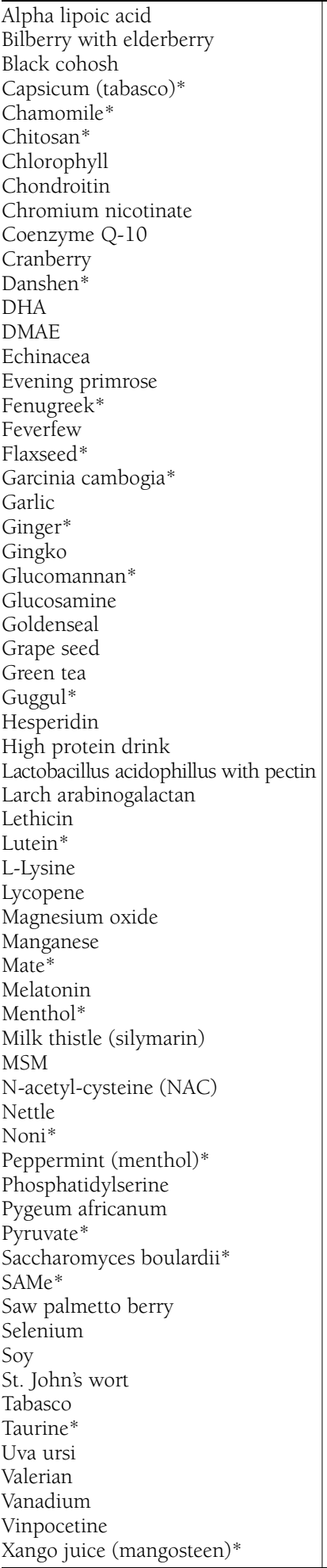 & $\begin{array}{l}\text { Creatine* } \\
\text { DHEA } \\
\text { Hawthorn } \\
\text { Kelp* } \\
\text { Raspberry* } \\
\text { Willow }\end{array}$ & $\begin{array}{l}\text { Androstenedione* } \\
\text { Bitter orange* } \\
\text { Blue cohosh* } \\
\text { Bromex } \\
\text { Cat's claw* } \\
\text { Chaparral* } \\
\text { Chromium picolinate } \\
\text { Country mallow* } \\
\text { Devil's claw* } \\
\text { Dong quai } \\
\text { Ephedrine } \\
\text { Ginseng } \\
\text { Kava kava } \\
\text { Ma huang } \\
\text { Sea cucumber }\end{array}$ \\
\hline
\end{tabular}

* Included in the 2004 guide but not the 2003 guide. actions was to solicit information from physicians, pharmacists, and dieticians to determine how familiar they were with CAM resources. The resounding response was that clinicians are often asked about CAM products but lack proper training and resources to respond. This finding is consistent with current literature.

Health Plans Pharmacy Services made the decision to form a CAM subcommittee of the pharmacy and therapeutics (P\&T) committee to evaluate current commonly used CAM products for efficacy and safety. Pharmacy Services recruited physicians and pharmacists from the Health Plans P\&T committee who expressed an interest in CAM. The same physician and pharmacist involved in the initial evaluation group were appointed cochairs of the CAM subcommittee. The pharmacist also recruited a faculty clinical pharmacist from the University of Utah with expertise and experience in CAM. Other recruited clinicians included dieticians and a representative from the Health Plans sales department. The final composition of the CAM subcommittee included 6 pharmacists (a Health Plans clinical pharmacist, the 2 pharmacy directors from Health Plans, the IMCO community pharmacy manager, a University of Utah clinical pharmacist, and a data analyst responsible for maintaining electronic records), 4 physicians (Health Plans P\&T chair, 2 other P\&T members, and an IMCO physician), 3 dieticians from the IMCO, a representative from Health Plans Sales and Marketing, and a certified pharmacy technician (CPhT) as project coordinator.

The goal and primary outcome measure of the CAM subcommittee was the development of a CAM guide listing recommendations for use of CAM products. Secondary outcome measures included results of a survey of clinicians regarding CAM use and usefulness of the guide (survey sent with guide), and acceptance of the guide, as reflected in the number of requests for copies, information, and speaking engagements.

\section{Results}

The CAM subcommittee of the P\&T committee began meeting monthly in November 2001. The first action items included identifying the evaluation criteria for products, Web sites, and programs; evaluating the IMCO's compliance policy; determining the information sources; and establishing the dissemination methods. The evaluation criteria for CAM agents were (1) the listing of proposed uses or common uses; (2) the listing of those indications that are supported by scientific evidence; (3) the listing of adverse events, drug interactions, and cautions; (4) dosing; (5) the listing of origin and formulations; and (6) recommendations for use. All CAM agents were ultimately evaluated under the heading of "Recommendation." The recommendations were either neutral, "use with extreme caution," or negative. Table 1 lists the evaluation criteria for products. Evaluation criteria for Web sites included Internet addresses; sponsoring organizations; purpose; scope of information; 


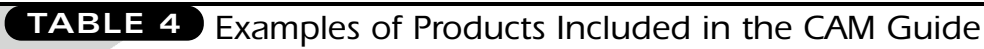

\begin{tabular}{|c|c|c|c|c|c|c|c|c|}
\hline \multirow[t]{2}{*}{ Product } & \multirow[t]{2}{*}{ Indication } & \multirow[t]{2}{*}{ Efficacy } & \multicolumn{3}{|c|}{ Safety } & \multirow[t]{2}{*}{ Dosing } & \multirow[t]{2}{*}{ Origin } & \multirow[t]{2}{*}{ Recommendation } \\
\hline & & & AEs & DIs & Cautions & & & \\
\hline Echinacea & $\begin{array}{l}\text { - Viral } \\
\text { respiratory } \\
\text { tract } \\
\text { infections } \\
\text { - Bacterial } \\
\text { sinusitis } \\
\text { - Pertussis } \\
\text { - Strep throat } \\
\text { - Recurrent } \\
\text { candida } \\
\text { infection } \\
\text { - Herpes } \\
\text { simplex } \\
\text { infection } \\
\text { - Wound } \\
\text { healing }\end{array}$ & $\begin{array}{l}\text { - Viral } \\
\text { respiratory } \\
\text { tract } \\
\text { infections } \\
\text { - Bacterial } \\
\text { - sinusitis } \\
\text { - Pertussis } \\
\text { - Strep throat } \\
\text { - Recurrent } \\
\text { candida } \\
\text { infection } \\
\text { - Herpes } \\
\text { simplex } \\
\text { infection }\end{array}$ & $\begin{array}{l}\text { - Possible } \\
\text { dizziness, } \\
\text { headache, } \\
\text { skin } \\
\text { irritations }\end{array}$ & $\begin{array}{l}\text { - Could } \\
\text { counteract } \\
\text { effects of } \\
\text { immuno- } \\
\text { suppressants } \\
\text { - BZDs, CCBs, } \\
\text { protease } \\
\text { inhibitors, } \\
\text { grapefruit } \\
\text { juice }\end{array}$ & $\begin{array}{l}\text { - Contra- } \\
\text { indicated in } \\
\text { MS, HIV, } \\
\text { autoimmune } \\
\text { diseases, and } \\
\text { TB } \\
\text { - Is not to be } \\
\text { used longer } \\
\text { than } 8 \text { weeks } \\
\text { consecutively } \\
\text { - Contra- } \\
\text { indicated in } \\
\text { pregnancy } \\
\text { by German } \\
\text { Commission E }\end{array}$ & $\begin{array}{l}\text { - Two } \\
\text { common } \\
\text { ways: } \\
\text { episodic- } \\
\text { 300-500 mg } \\
\text { TID-QID x } \\
\text { 1-2 weeks; } \\
\text { preventive- } \\
\text { 150-300 mg } \\
\text { BID } \\
\text { "Cycling" is } \\
\text { advised for } \\
\text { extended } \\
\text { dosing }\end{array}$ & $\begin{array}{l}\text { - Supplied as } \\
\text { a dried root } \\
\text { or herb, } \\
\text { capsule, } \\
\text { tablet, tea, } \\
\text { tincture, } \\
\text { fluid extract, } \\
\text { solid extract, } \\
\text { cream, lotion, } \\
\text { and salve }\end{array}$ & $\begin{array}{l}\text { - Well documented for use } \\
\text { in viral respiratory tract } \\
\text { infections } \\
\text { - Should not replace appro- } \\
\text { priate therapy for bacterial } \\
\text { sinusitis, strep throat, } \\
\text { candida infection, and } \\
\text { herpes simplex infection } \\
\text { - Should not be used longer } \\
\text { than } 8 \text { consecutive weeks } \\
\text { - Contraindicated in } \\
\text { immunosuppression, TB, } \\
\text { and autoimmune disease }\end{array}$ \\
\hline Kava Kava & $\begin{array}{l}\text { - Stress, } \\
\text { anxiety, } \\
\text { tension } \\
\text { - Insomnia } \\
\text { - Postmeno- } \\
\text { pausal } \\
\text { symptoms } \\
\text { - Analgesic } \\
\text { - Antibacterial, } \\
\text { antifungal } \\
\text { - Anticonvul- } \\
\text { sant } \\
\text { - Muscle } \\
\text { relaxant } \\
\text { - Is used } \\
\text { ceremonially } \\
\text { by Pacific } \\
\text { Islanders }\end{array}$ & $\begin{array}{l}\text { - Tension, } \\
\text { anxiety, and } \\
\text { excitement }\end{array}$ & $\begin{array}{l}\text { - Liver toxicity } \\
\text { (hepatitis, } \\
\text { LFTs) } \\
\text { - Hangover, } \\
\text { fatigue, } \\
\text { drowsiness } \\
\text { - Vision abnor- } \\
\text { malities } \\
\text { - Dermopathy } \\
\text { - Decreased } \\
\text { motor } \\
\text { reflexes or } \\
\text { judgment }\end{array}$ & $\begin{array}{l}\text { - Alcohol } \\
\text { - Psycho-active } \\
\text { meds } \\
\text { - Benzodi- } \\
\text { azepines }\end{array}$ & $\begin{array}{l}\text { - Contra- } \\
\text { indicated in } \\
\text { pregnancy } \\
\text { and lactation } \\
\text { - Should not } \\
\text { be used in } \\
\text { people with } \\
\text { endogenous } \\
\text { depression }\end{array}$ & $\begin{array}{l}\text { - } 150-300 \mathrm{mg} \\
\text { of root } \\
\text { extract BID } \\
\text { - As long as } \\
8 \text { weeks may } \\
\text { be needed to } \\
\text { see effect } \\
\text { - Continuous } \\
\text { treatment for } \\
>3 \text { months is } \\
\text { not recom- } \\
\text { mended }\end{array}$ & $\begin{array}{l}\text { - Root extract } \\
\text { - Activity is } \\
\text { highly } \\
\text { dependent } \\
\text { on type of } \\
\text { kavapyrone } \\
\text { used }\end{array}$ & $\begin{array}{l}\text { - Advise not to use- } \\
\text { Implicated in cases of seri- } \\
\text { ous liver toxicity (hepati- } \\
\text { tis, cirrhosis, and liver } \\
\text { failure), CI in pregnancy, } \\
\text { and has dosing restrictions } \\
\text { - Evidence to support use } \\
\text { in anxiety } \\
\text { - Is German Commission E } \\
\text { approved for treatment of } \\
\text { nervous anxiety, stress, } \\
\text { and restlessness. However, } \\
\text { has been prohibited for } \\
\text { sale in Germany and some } \\
\text { other European countries } \\
\text { - Ingredient of Tension and } \\
\text { Mood product }\end{array}$ \\
\hline Raspberry (Red) & $\begin{array}{l}\text { - Respiratory } \\
\text { problems } \\
\text { (asthma, } \\
\text { bronchiole } \\
\text { spasms) } \\
\text { - UTIs } \\
\text { - Diabetes } \\
\text { - Diarrhea } \\
\text { - Dysmenor- } \\
\text { rhea, } \\
\text { menorrhagia, } \\
\text { morning } \\
\text { sickness, } \\
\text { facilitation } \\
\text { of labor and } \\
\text { delivery }\end{array}$ & $\begin{array}{l}\text { - No efficacy } \\
\text { data are } \\
\text { available }\end{array}$ & $\begin{array}{l}\text { - Increased } \\
\text { blood } \\
\text { pressure, } \\
\text { decrease } \\
\text { in SBP } \\
\text { - Cariogenicity }\end{array}$ & $\begin{array}{l}\text { - Unknown } \\
\text { - May affect } \\
\text { absorption } \\
\text { of metformin; } \\
\text { sedative- } \\
\text { hypnotics, } \\
\text { antidepres- } \\
\text { sants, } \\
\text { tranquilizers; } \\
\text { iron, calcium, } \\
\text { magnesium }\end{array}$ & $\begin{array}{l}\text { - Contra- } \\
\text { indicated in } \\
\text { raspberry } \\
\text { hyper- } \\
\text { sensitivity } \\
\text { - May initiate } \\
\text { or reduce } \\
\text { uterine } \\
\text { contractions } \\
\text { (should not } \\
\text { be used } \\
\text { during } \\
\text { pregnancy } \\
\text { without } \\
\text { medical } \\
\text { supervision) }\end{array}$ & $\begin{array}{l}\text { - Widely varies } \\
\text { based on } \\
\text { source }\end{array}$ & $\begin{array}{l}\text { - Many tea } \\
\text { products } \\
\text { may be green } \\
\text { or black tea } \\
\text { flavored with } \\
\text { raspberry } \\
\text { flavor (do } \\
\text { not have } \\
\text { same } \\
\text { therapeutic } \\
\text { properties) }\end{array}$ & $\begin{array}{l}\text { - No efficacy data are } \\
\text { available } \\
\text { - Should not be used } \\
\text { during pregnancy without } \\
\text { medical supervision (may } \\
\text { initiate or reduce uterine } \\
\text { contractions and may alter } \\
\text { blood pressure) }\end{array}$ \\
\hline $\begin{array}{l}\text { Saw Palmetto } \\
\text { Berry }\end{array}$ & $\begin{array}{l}\text { - } \text { BPH } \\
\text { - Androgen- } \\
\text { induced acne }\end{array}$ & - BPH & $\begin{array}{l}\text { - Nausea, } \\
\text { pruritis, } \\
\text { abdominal } \\
\text { pain, } \\
\text { headache }\end{array}$ & - Unknown & $\begin{array}{l}\text { - Caution in } \\
\text { hormone- } \\
\text { dependent } \\
\text { cancer } \\
\text { - Avoid han- } \\
\text { dling by } \\
\text { pregnant } \\
\text { women } \\
\text { (may be } \\
\text { teratogenic) }\end{array}$ & $\begin{array}{l}\text { - 1-2 grams } \\
\text { of berry or } \\
320 \mathrm{mg} \\
\text { lipophilic } \\
\text { ingredients } \\
\text { daily }\end{array}$ & & $\begin{array}{l}\text { - Evidence to support use } \\
\text { for treatment of symptoms } \\
\text { of BPH } \\
\text { - German Commission E } \\
\text { approved for urinary } \\
\text { problems of BPH stage I } \\
\text { and stage II } \\
\text { - Avoid handling by } \\
\text { pregnant women } \\
\text { - Caution not to delay } \\
\text { appropriate therapy }\end{array}$ \\
\hline
\end{tabular}

$A E=$ adverse event $B I D=$ twice daily; $B P H=$ benign prostatic hyperplasia; $B Z D=$ benzodiazepine; $C C B=$ complete blood count; $C I=$ contraindicated; $D I=$ drug interaction; $H I V=$ human immunodeficiency virus; $L F T=$ liver function test; $M S=$ multiple sclerosis; $2 I D=$ four times daily; $S B P=$ systolic blood pressure; $T B=$ tuberculosis; 
TABLE 5 Results of the CAM Guide Survey-Year 1 (2003)

\begin{tabular}{|c|c|c|}
\hline & Physician & Pharmacist \\
\hline Response rate & $13 \%(65$ of $\sim 500)$ & $10 \%(19$ of $\sim 200)$ \\
\hline \multicolumn{3}{|c|}{ Question 1: How often do you counsel on herbals? } \\
\hline Never & $7.5 \%$ & $0 \%$ \\
\hline$<1$ time a month & $10.4 \%$ & $11.1 \%$ \\
\hline$<1$ time a week & $20.9 \%$ & $11.1 \%$ \\
\hline Weekly & $44.8 \%$ & $38.9 \%$ \\
\hline Daily & $16.4 \%$ & $38.9 \%$ \\
\hline \multicolumn{3}{|c|}{ Question 2: How do you feel about CAM? } \\
\hline Don't believe it works & $21.4 \%$ & $8.7 \%$ \\
\hline Don't believe it is safe & $24.3 \%$ & $4.3 \%$ \\
\hline $\begin{array}{l}\text { Is a good alternative to } \\
\text { prescription medications }\end{array}$ & $10.0 \%$ & $26.1 \%$ \\
\hline $\begin{array}{l}\text { Is a good add-on to } \\
\text { prescription medications }\end{array}$ & $40.0 \%$ & $60.9 \%$ \\
\hline Don't care & $4.3 \%$ & $0 \%$ \\
\hline \multicolumn{3}{|c|}{ Question 3: How much interest do you have in CAM? } \\
\hline No interest & $10.6 \%$ & $0 \%$ \\
\hline Some interest & $71.2 \%$ & $57.9 \%$ \\
\hline Very interested & $18.2 \%$ & $42.1 \%$ \\
\hline \multicolumn{3}{|c|}{ Question 4: How would you rate your knowledge of CAM? } \\
\hline None & $3.0 \%$ & $0 \%$ \\
\hline Below average & $30.3 \%$ & $26.3 \%$ \\
\hline Average & $42.4 \%$ & $31.6 \%$ \\
\hline Above average & $24.2 \%$ & $26.3 \%$ \\
\hline Excellent & $0 \%$ & $15.8 \%$ \\
\hline
\end{tabular}

Question 5: How have you seen the use of CAM change in the past year?

\begin{tabular}{l|c|c}
\hline Significant decrease & $0 \%$ & $0 \%$ \\
\hline Slight decrease & $0 \%$ & $5.3 \%$ \\
\hline No change & $42.9 \%$ & $15.8 \%$ \\
\hline Slight increase & $46.0 \%$ & $57.9 \%$ \\
\hline Significant increase & $11.1 \%$ & $21.1 \%$ \\
\hline
\end{tabular}

Question 6: How helpful will this guide be as a counseling aide?

\begin{tabular}{l|c|c}
\hline Don't know & $10.9 \%$ & $5.3 \%$ \\
\hline Not helpful & $0 \%$ & $5.3 \%$ \\
\hline Somewhat helpful & $45.3 \%$ & $31.6 \%$ \\
\hline Very helpful & $43.8 \%$ & $57.9 \%$ \\
\hline Question 7: Check your location. & \multicolumn{2}{|l}{} \\
\hline Northern Utah/Idaho & $14.1 \%$ & $16.7 \%$ \\
\hline Weber County/North Davis County & $10.9 \%$ & $5.6 \%$ \\
\hline South Davis County/Salt Lake County & $57.8 \%$ & $33.3 \%$ \\
\hline Utah County & $6.3 \%$ & $0 \%$ \\
\hline Central Utah/Southern Utah & $10.9 \%$ & $44.4 \%$ \\
\hline Other & $0 \%$ & $0 \%$ \\
\hline
\end{tabular}

Question 8: Check your type of practice/pharmacy.

\begin{tabular}{l|c|c}
\hline Independent & & $73.7 \%$ \\
\hline Regional chain & & $15.8 \%$ \\
\hline National chain & & $0 \%$ \\
\hline Associated with a hospital or clinic & & $10.5 \%$ \\
\hline Family practice & $30.8 \%$ & \\
\hline Internal medicine & $21.5 \%$ & \\
\hline Specialty & $47.7 \%$ & \\
\hline Other & $0 \%$ & $0 \%$ \\
\hline
\end{tabular}

assessment of accuracy, quality, and objectivity; ease of use; weaknesses, disadvantages, or cautions; and overall impression.

Information sources that were utilized by the subcommittee are listed in Table 2. The products included in the CAM guide are shown in Table 3. Annual publishing of a CAM guide was anticipated, with monthly updates distributed to pharmacists and updates provided in the P\&T newsletter. The monthly updates were provided to IMCO pharmacies via e-mail and were prepared by the Health Plans' clinical pharmacist, community pharmacy manager, and pharmacy data steward. The P\&T newsletter is mailed to all physicians in the network on a quarterly basis.

A CAM guide was first printed in paperback form for distribution in January 2003. The first guide was pocket-sized, with 25 pages. After disseminating the guide to providers, the subcommittee reduced meetings to a quarterly schedule. In January 2004, an updated version of the guide, comprising 38 pages, was disseminated. The first guide was sent to all IMCO-employed physicians, all pharmacies in the IMCO network, and to selected IMCO-affiliated dieticians and nutritionists. The insurance division of the IMCO (Health Plans) sent the second version of the guide only to selected IMCOemployed physicians and affiliated dieticians and nutritionists, and to smaller regional, IMCO-owned, or independent pharmacies in 2004. An electronic version of the CAM guide was developed in the fall of 2003 and was made downloadable to handheld devices. It is also accessible to IMCO-employed providers at http://IHCRx. Further annual updates are planned.

Table 4 lists four examples of products included in the CAM guide. The 2004 CAM guide includes 85 individual CAM products that have been evaluated and assigned a recommendation. Fifteen products have been given a negative evaluation and are not recommended for use. These products are androstenedione, bitter orange, blue cohosh, Bromex, cat's claw, chaparral, chromium picolinate, country mallow, devil's claw, dong quai, ephedrine andma huang (since banned in the United States by the FDA), ginseng, kava kava, and sea cucumber. Creatine, DHEA, hawthorn, kelp, raspberry, and willow received the recommendation of "use with extreme caution."

The survey of clinicians was distributed with both the 2003 and 2004 CAM guides. The response rate to the 2003 survey was low (Table 5). Only 13\% of physicians and $9.5 \%$ of pharmacists ret u med the survey. Of the respondents, $89 \%$ of pharmacists and physicians felt that the guide would be somewhat or very helpful as a counseling aide, $11 \%$ of physicians were unsure, and one pharmacist (from a regional chain) felt the guide would be unhelpful as a counseling aide.

In an effort to increase the response rate, an incentive was included in the 2004 survey. Everyone who returned a survey was sent a movie rental gift card. More clinicians returned the 2004 survey (37\% of physicians and $26 \%$ of pharmacists, Table 6). The 2003 and 2004 surveys were of similar design-the only 
difference was that the 2004 survey included a question concerning the helpfulness of the 2003 guide. In 2004, 78\% of physicians and $97 \%$ of pharmacists responded that the guide would be somewhat or very helpful as a counseling aide. Seven percent of physicians and 3\% of pharmacists felt the guide would not be helpful. When asked about the previous version of the guide, $47 \%$ of physicians felt the guide was somewhat or very helpful, $7 \%$ felt it was not helpful, and $46 \%$ responded that they had not received a guide. In comparison, $51 \%$ of pharmacists felt the guide was somewhat or very helpful, $5 \%$ felt it was not helpful, and 44\% responded that they had not received a guide. Tables 5 and 6 report the results of the surveys.

The IMCO Health Plans clinical phamacist/committee cochair has spoken to many different groups (including dieticians, pharmacists, physicians, and IMCO management) about CAM products and the guide. This individual has addressed the IMCO network management conference, the IMCO-wide annual dietician conference, and employer groups, among others.

\section{Discussion}

CAM is a potentially important component of health care. Patients are increasingly using CAM products, and responsible clinicians must be able to help their patients answer questions. A scientifically based, easy-to-use CAM guide, therefore, has the potential to have a large impact for an MCO. It helps to meet competitive market demands and provides ongoing education to clinicians. It also has the potential to increase the credibility of CAM products and improve patient perception of these products by providing evidence-based information. An important component of an endeavor like this is the relationship of the IMCO and the CAM vendor. IMCO Health Plans has a partnership with its vendor and was thus able to review the products offered through its network and remove items where necessary. This IMCO is also able to control the promotional materials that are associated with CAM products.

Many references do not meet all of the criteria provided in the CAM guide of this IMCO. For example, MICROMEDEX is an excellent comprehensive reference that includes scientific evidence and clinical trial results, but it does not provide a recommendation for use. Many clinicians also lack easy access to MICROMEDEX as well as many other commonly used references. These other references may also not be complete, may be expensive to purchase and difficult to update, and may be burdensome to use due to size or location in the facility. The CAM guide of this IMCO was designed with the clinician in mind. It is a pocket-sized booklet, also available in an electronic version that may be downloaded to a clinician's personal digital assistant. All evaluated products are listed in alphabetical order for easy searching.

The surveys that accompanied both guides illustrate general differences between physician and pharmacist attitudes toward CAM. In this population, more physicians felt that CAM is
TABLE 6 Results of the CAM Guide Survey-Year 2 (2004)

Physician $\quad$ Pharmacist

\begin{tabular}{l|c|c}
\hline Response rate & Physician & Pharmacist \\
\hline
\end{tabular}

Question 1: How often do you counsel on herbals?

\begin{tabular}{|c|c|c|}
\hline Never & $3.2 \%$ & $0 \%$ \\
\hline$<1$ time a month & $17.9 \%$ & $11.1 \%$ \\
\hline$\overline{<l \text { time a week }}$ & $23.2 \%$ & $30.2 \%$ \\
\hline Weekly & $44.2 \%$ & $27.0 \%$ \\
\hline Daily & $11.6 \%$ & $31.7 \%$ \\
\hline \multicolumn{3}{|c|}{ Question 2: How do you feel about CAM? } \\
\hline Don't believe it works & $21.4 \%$ & $11.5 \%$ \\
\hline Don't believe it is safe & $24.6 \%$ & $15.4 \%$ \\
\hline $\begin{array}{l}\text { Is a good alternative to prescription } \\
\text { medications }\end{array}$ & $11.1 \%$ & $16.7 \%$ \\
\hline $\begin{array}{l}\text { Is a good add-on to prescription } \\
\text { medications }\end{array}$ & $40.5 \%$ & $53.8 \%$ \\
\hline Don’t care & $2.4 \%$ & $2.6 \%$ \\
\hline
\end{tabular}

Question 3: How much interest do you have in CAM?

\begin{tabular}{|l|c|c|}
\hline No interest & $10.6 \%$ & $6.3 \%$ \\
\hline Some interest
\end{tabular}

\begin{tabular}{l|l|l}
\hline Some interest & $78.7 \%$ & $65.1 \%$ \\
\hline
\end{tabular}

\begin{tabular}{|c|c|}
\hline Very interested & $10.6 \%$ \\
\hline
\end{tabular}

Question 4: How would you rate your knowledge of CAM?

\begin{tabular}{l|c|c}
\hline None & $1.1 \%$ & $0 \%$ \\
\hline Below average & $28.7 \%$ & $25.4 \%$ \\
\hline Average & $46.8 \%$ & $54.0 \%$ \\
\hline Above average & $21.3 \%$ & $17.5 \%$ \\
\hline Excellent & $2.1 \%$ & $3.2 \%$
\end{tabular}

Question 5: How have you seen the use of CAM change in the past year? \begin{tabular}{|l|c|c|}
\hline Significant decrease & $0 \%$ & $0 \%$
\end{tabular}

\begin{tabular}{l|c|c}
\hline Slight decrease & $4.3 \%$ & $4.8 \%$ \\
\hline No change & $55.3 \%$ & $39.7 \%$ \\
\hline Slight increase & $31.9 \%$ & $42.9 \%$
\end{tabular}

Slight increase

Significant increase

$8.5 \%$

$12.7 \%$

Question 6: How helpful will this guide be as a counseling aide?

Don't know

Not helpful

Somewhat helpful

Very helpful

\begin{tabular}{l|l}
\hline $15.2 \%$ & $0 \%$ \\
\hline $6.5 \%$ & $3.2 \%$
\end{tabular}

Question 6b: How helpful was the previous version of this guide during the past year?

\begin{tabular}{l|c|c}
\hline Didn't receive a guide & $46.2 \%$ & $44.4 \%$ \\
\hline Not helpful & $6.6 \%$ & $4.8 \%$ \\
\hline Somewhat helpful & $37.4 \%$ & $28.6 \%$ \\
\hline Very helpful & $9.9 \%$ & $22.2 \%$
\end{tabular}

Question 7: Check your location.

\begin{tabular}{|l|l|l|}
\hline Northern Utah/Idaho & $9.7 \%$ & $31.3 \%$
\end{tabular}

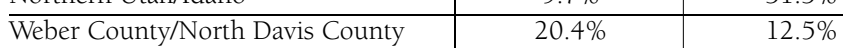

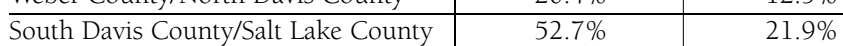

Utah County

Central Utah/Southern Utah

Other

$8.6 \%$

$8.6 \%$

$0 \%$

$18.5 \%$

Question 8: Check your type of practice/pharmacy.

\begin{tabular}{l|c|c}
\hline Independent & & $71.4 \%$ \\
\hline Regional chain & & $11.1 \%$ \\
\hline National chain & & $3.2 \%$ \\
\hline Associated with a hospital or clinic & & $14.3 \%$ \\
\hline Family practice & $54.8 \%$ & \\
\hline Internal medicine & $20.4 \%$ & \\
\hline Specialty & $24.7 \%$ & \\
\hline Other & $0 \%$ & \\
\hline
\end{tabular}


either ineffective or unsafe, while more pharmacists tend to believe that CAM is a good alternative to, or add-on to, prescription medications. This difference may be due to familiarity with CAM, interest in CAM, and experience with counseling. More pharmacists than physicians rated their knowledge of CAM as either above average or excellent. These findings were consistent from year 1 to year 2 .

Much of the success of this project was due to a direct and important relationship between the CAM P\&T subcommittee and the Health Plans P\&T committee. Many of the subcommittee's members came from the Health Plans committee. Also, the full Health Plans P\&T committee ultimately reviewed and accepted the recommendations of the subcommittee and supported this project by providing access to the Health Plans P\&T newsletter, provider networks, and provider groups for educational and speaking purposes.

Among the limitations of this project was the absence of an estimate of the administrative costs to create the CAM. The only direct costs associated with this project were the printing price for the CAM guide (approximately $\$ 1,000$ each year), the gift cards used with the surveys (approximately 300 cards at $\$ 5$ each), and mailing costs for the CAM guide. All of the other costs were indirect. All CAM P\&T subcommittee members donated their time for this project. The committee was not paid for participating in the meetings, preparing information, research, travel, or for presentations given to other health care professionals. On the other hand, time was used for this project that could have been spent on other projects, and the maintenance of electronic records required resources taken from other projects. Second, there was probable bias in the responses to the first survey due to the very low response rate, and some response bias could have been created in the second survey by offering gift cards to respondents. Third, CAM medications are not a covered pharmacy benefit for this IMCO, so the impact of the CAM guide on appropriate utilization of CAM products cannot be measured because of the absence of pharmacy claims. Fourth, it would be useful to determine the continued willingness of the IMCO to fund the continued work of the subcommittee and production of the CAM guide, with possible expanded availability to members and patients of this IMCO.

\section{Conclusion}

A scientifically based CAM guide was developed by a P\&T subcommittee consisting of a multidisciplinary team of clinicians and administrative personnel. Two surveys of IMCO physicians and pharmacists indicated that the guide was well accepted and had a positive impact on the IMCO. The guide is easy to use; it is available to providers online and is downloadable to handheld devices.

\section{ACKNOWLEDGMENTS}

The authors would like to acknowledge the contributions of Nancy Alcabes, MBA; Curtis Andersen, MD; Johnnie Cook, MD; Amie Heap, RD CNSD; Robert Hooten, PharmD; Kathleen Nielsen, RD CD; K. Bethe Price, CPhT; Jennifer Thornock, RD CD; Jeffrey Twitchell, MD; and Darryl B. Wagner, RPh, of Intermountain Health Care, Salt Lake City, Utah, for their participation on the CAM subcommittee.

\section{DISCLOSURES}

No outside funding supported this study. Authors Jeffrey D. Dunn, H. Eric Cannon, and Tamara Lewis are employees of Intermountain Health Care, whose CAM guide is the subject of this article; they disclose no potential bias or conflict of interest relating to this article. Author Laura Shane-McWhorter discloses no potential bias or conflict of interest relating to this article; she is on the speakers bureau for Aventis, Bayer, Roche, and AstraZeneca pharmaceutical companies.

Dunn served as principal author of the study. Study concept and design were contributed by all authors. Analysis and interpretation of data were contributed by Dunn and Lewis. Drafting of the manuscript was primarily the work of Dunn, and its critical revision was the work of Cannon, Lewis, and Shane-McWhorter. Administrative, technical, and/or material support was provided by Cannon.

\section{REFERENCES}

1. Angell M, Kassirer JP. Alternative medicine-the risks of untested and unregulated remedies. N Engl J Med. 1998;339(12):839-41.

2. Dietary Supplement Health and Education Act of 1994. Available at: http://www.fda.gov/opacom/laws/dshea.html. Accessed October 24, 2001.

3. National Center for Health Statistics National Health Interview Survey, 2002. Available in part at: http://nccam.nih.gov/news/camsurvey_fsl.htm. Accessed January 29, 2005.

4. National Center for Complementary and Alternative Medicine. Available at: http://nccam.nih.gov. Accessed January 29, 2005.

5. Kaufman DW, Kelly JP, Rosenberg L, Andersen TE, Mitchell AA. Recent patterns of medication use in the ambulatory adult population of the United States: the Slone survey. JAMA. 2002;287(3):337-44.

6. NIH News Advisory. Exploring the scientific basis of complementary and alternative medicine. Available at: http://www.nih.gov/news/pr/mar2002/ nccam-08.htm. Accessed October 14, 2004.

7. Bluming A. The alternative medicine handbook: the complete reference guide to alternative and complementary therapies; alternative medicine and ethics. N Engl J Med. 1998;39(12):855-56.

8. NIH News Advisory. Town meeting on complementary and alternative medicine research in Boston, MA. Available at: http://www.nih.gov/news/ pr/feb2000/nccam-24.htm. Accessed October 14, 2004.

9. Clinical practice guidelines in complementary and alternative medicine. An analysis of opportunities and obstacles. Practice and Policy Guidelines Panel, National Institutes of Health Office of Alternative Medicine. Arch Fam Med. 1997;6(2):149-54. 